\title{
Factors Affecting the Quality of English Language Teaching in Preparatory Year, University of Jeddah
}

\author{
Maysoon A. Dakhiel ${ }^{1}$ \\ ${ }^{1}$ Faculty of Education, University of Jeddah, Saudi Arabia \\ Correspondence: Maysoon A. Dakhiel, Faculty of Education, University of Jeddah, Saudi Arabia
}

Received: April 15, 2017 Accepted: May 27, 2017 Online Published: May 30, 2017

doi: 10.5539/elt.v10n7p43 URL: http://doi.org/10.5539/elt.v10n7p43

\begin{abstract}
Several Universities in Saudi Arabia have recently made it their priority to pursuit excellence in effective EFL teaching-learning starting from the Preparatory Year Program (PYP). That is due to the rapid expansion of English as a lingua franca in tertiary education especially in science and technology, scientific and educational publication, technology, internet communication, etc. The present study will examine the current situation in EFL teaching and learning to identify the factors affecting the quality of English language teaching in the PYP at Jeddah University. When studying quality in EFL teaching, the concentration is usually put on the teacher where in fact the success of the operation is collaboration between three major constituents of the program triangle, the learners, the teachers and the institution. Therefore, these three constituents were asked to first identify what they think is important in regards to the quality of the EFL program, and what impedes achieving its goals. In order to identify and analyze the factors, this study applied the following survey: Quality in Language Teaching for Adults developed by Grundtvig Learning Partnership (2009-2011), on teachers, learners, and administrators. Slight variations in wording of the survey statements was implemented in order to suit each group. For data analysis, SPSS software was used. Recommendations and further fields of study presented were based on the findings.
\end{abstract}

Keywords: Saudi Arabia, preparatory year, EFL, EFL teaching, EFL learning

\section{Introduction}

Teaching English in Saudi Arabia began early in the late 1920s (Al-Seghayer, 2005). Yet, since then and until the present time, the level of students' EFL proficiency and achievement has been identified as weak (Al-Khairy, 2013a; Alrabai, 2014a; Alrahaili, 2013; Alrashidi \& Phan, 2015; Elyas \& Picard, 2010; Rahman \& Alhaisoni, 2013; etc.). Even though the successive education ministries have spent huge amount of efforts and funds to ensure the achievement of the language program objectives, the problem still exists. For this and several other reasons, Saudi universities decided to include a preparatory year program (PYP) in order to bridge the knowledge and skill gap between the school and the university to secure a smooth transition.

Today in Saudi Arabia, there are 30 public and 9 private universities. All of the public universities and some of private ones introduced the PYP as prerequisite to enter the 4 years specialized fields. Entrance to the specialized field is decided upon the set GPA by each school. Since several colleges are providing the courses in English such as medicine, engineering, computer science and business, each university in turn included an EFL program within the PYP to try to remedy students' EFL low proficiency level among other problems encountered with the general education output. Even though most institutions of higher education in Saudi Arabia do not use English as the main language of instruction, but the trend is moving towards implementing programs that use English as the main language of instruction (Al-Attas, Omar, \& Yushuau 2006). Thus, the English language gained an important status and is designated a major role by assigning it as a compulsory subject in the PYP. Furthermore, since the number of contact number is higher than the rest of the subjects, it outweighs the importance of the other components of the PYP program such as Arabic, Math, Science, critical thinking and communications skills.

Most of the research conducted on the quality of teaching English as a foreign language (EFL) has mainly focused on either teachers or students. Yet, the researcher has not found any that included the administrative staff who cater for the program's students and teachers. When conducting an analytical study that takes into account the perceptive of these three constituents, this process will contribute to arriving at a more holistic view of what constitutes an effective EFL program and identifying the factors that impedes the quality of executing implementation. Therefore, 
this study aims to identify factors that affect the EFL teaching at Jeddah University Preparatory Year (PYP) from the perspectives of teachers, administrators and students. Subsequently to suggest the changes or additions needed to fill in the gaps when evaluating the program for upgrading.

\subsection{Questions of the Study}

1) What are the factors that affect the quality of an EFL teacher from the perspective of the teachers, students and campus staff?

2) What are the factors that affect EFL teacher instruction from the perspective of the teachers, students and campus staff?

3) What are the factors that affect the EFL course from the perspective of the teachers, students and campus staff?

4) What are the factors that affect the institution from the perspective of the teachers, students and campus staff?

5) What are the factors that affect EFL student learning from the perspective of the teachers, students and campus staff?

6) What are the suggestions to reduce the problems faced by the teachers, administrators and students of the EFL program in the PYP at Jeddah University?

\subsection{Significance of the Study}

Since EFL carries such a significant role, it is only understandable when one endeavors to study the quality of the EFL teaching program. And that is to further our understanding of the factors that are positively or negatively affecting the execution and to enrich the literature in the field of EFL instruction and learning. Thus, it is never a wasted effort but rather an imperative one. The goal is to bridge the gap for our students be it in language or knowledge and we will not be able to achieve that if we do not revise and develop on continuous bases. Here, research comes in and opens an outside window to look in, diagnose, analyze and produce solutions. This study is one these windows. Furthermore, it will serve as start for further explorations with other factors linked to EFL program development, implementation, and assessment.

\subsection{Limitation}

This study is limited to female EFL teachers, students, and administrators catering for the PYP at Jeddah University during the 1st semester of the academic year 2016/2017.

\subsection{Study Terms}

For the purpose of this study, the following terms will have the associated definitions:

Preparatory Year: In some of the Saudi universities a preparatory year was developed and implemented as pre-academic preparatory courses, designed to prepare students for admission into the university colleges. It has been added to fill the gap of knowledge and skills needed to help students enter the required majors with ease and manage the various undergraduate level by providing them with the basic necessary basic skill for university study. It consists of two semesters which most admitted students at the university must join.

English Language Program: English language programs provide a variety of courses for academic English for university-bound students. These programs are expected to have a professionally trained faculty; instructors, developers and administrators, in addition to an excellent curriculum, and adequate facilities for study. These facilities usually include classrooms equipped with computers and projectors, libraries, language laboratories, and other equipment. As for the courses the instruction is executed through small group discussions, language labs, and out-of-class work. Students also attend regular academic classes in other subjects given by the preparatory year.

Administrators: All the university staff from high administration level to building proctors, who usually come in contact with the preparatory year students. Some are connected to the English Language Program while others to the university as whole. They include: program developers, program administrators, student academic and social services, building proctors and heads of departments.

\subsection{Literature Review}

Several Arab and non-Arab studies, concerned with the teaching and learning English language were conducted. As well as those related to the necessary factors that affect the success of the English language program has also been investigated. Examples of such studies are:

In a study by Al-Seweed and Daif-Allah (2013) a survey was administered on student learning outcomes in a 
EFL program in Qassim University, Kingdom of Saudi Arabia. It investigated the effectiveness of an Intensive Preparatory English Language Module (IPELM), developed by the researcher, in preparing students to study in English at the university. The sample consisted of 1412 EFL novice Preparatory Year Program students, 69 EFL native and non-native English speaking teachers, and $10 \mathrm{EFL}$ focus group members. The sample's feedback on the execution of the IPELM program was obtained using quantitative and qualitative sources. It was found that the course was effective in addressing novice learners' academic orientation needs. It also prepared students to enter the preparatory year program and helped students to adapt to university learning environment. It also served as a guided for instructors to identify and implement specifics factors about students' needs to navigate in the program. Notice here that the administrators were not included in determining the success of the program.

A study by Al-Sharqi, Hashim and Ahmed (2014) set to identify possible factors that impede or motivate learning of the English language at the King Abdul-Aziz University's preparatory year program. A survey was applied on students and instructors of preparatory year program. The results illustrated some factors that affected faced students learning which include attitudinal, difficulty in switching from L2 to L1 and inefficient English language teaching and learning programs in schools. The study also identified and discussed the results of a blended learning experiment which yielded a positive outcome. Again, the study concentrated only students and instructors and not administrators. In addition, no mention of facilities nor textbooks or study materials was included.

Similarly, a study at the University of the East in Manila, was conducted by Salimi, E. and Farsi, M. (2012) to evaluate the English Language Proficiency Program for Foreign graduate level students (ELPPS). The study examined the program effects on the academic performance of foreign students. Several aspects of the program were looked into such as: course syllabi, goals and objectives, program content, strategies and methodology of instruction, faculty profile and program duration. The study also sought to determine if the English training programs pass William Dunn's four evaluation criteria, namely: effectiveness, responsiveness, appropriateness and adequacy. The sample of the study included all the foreign students enrolled in second semester of 2011-2012 in Master and Doctorate courses. The results indicated that the sample group of graduate students enrolled in the ELPPFS program assessed a significant positive change in their academic performance as a result of their enrollment in the program.

A study by Al-Jamal, D. and Al-Jamal, G. (2014) aimed at identifying that could be encountered at an EFL setting. The study sample was composed of a stratified random drawn from six Jordanian public universities. 566 students responded to the survey questionnaires. Also, semi-structured interviews were administered to 64 students. The findings of the study showed a apparent failure of EFL students' speaking skill in English together with reasons that explained such difficulty. Furthermore, study results exposed a 'low' speaking proficiency level among EFL undergraduates along with insignificant instruction of the speaking skill at university courses' level. Other difficulties that surfaced by study were: communication in L1, large classes, and lack of time. This study helps in shedding some light on factors that impede language learning in a EFL program such as time and the size of classes, in addition to the provision of ample avenues for communication in the target language.

Al-Nasser, A. (2015) conducted a study aimed at finding out the school students' language learning difficulties. In addition to the review of literature which tracked the teaching of EFL in Saudi Arabia back to the beginnings, the researcher collected data through unstructured interviews with 7 students studying English at the school level. He also conducted unstructured interviews with teachers and headmasters. Data was analyzed statistically. Some of the problems which the study identified and illustrated were: teachers' training, syllabus/curriculum content, methodology and tools of teaching as well as use of modern technology and modern infrastructure. Yet the most significant finding is that in student's minds as a result of the inadequate EFL program, they fear language learning which discourage them and keep them from participating, thus viewing it as an unnecessary interruption to their school education experience. The study recommended the introduction of English from early stages, concentration on quality not quantity in regard to curriculum and materials used, emphasis on evaluation not examination, class size, use of educational technologies for instruction, and the increase of number of contact hours per week. This study identified the high school graduate's EFL level and the difficulties of implementing the program. This helps us in the present study to connect to such factors and see if they are still present in the higher education EFL program.

\section{Method}

\subsection{Participants}

Participants of this study who were divided into three main groups were teachers, administrators and students. All participants were from Jeddah University. The teachers and students were from the $P Y P$, and the administrators 
were campus administrators serving the PYP program as well as the other programs on campus. The teachers' group consisted of 22 teachers working at Jeddah University ELT Center. The administrators' group consisted of 4 EFL coordinators and 8 general administration staff members. The students' group consisted of 195 first semester English learner from the PYP program.

\subsection{Instrument}

An electronic survey comprising five sections (48 items based on Likert Scale and two open-ended questions) was adopted from the study entitled "Quality in Language Teaching for Adults" (Grundtvig Learning Partnership 2009-2011). The survey was in two versions one in English for the EFL teachers and coordinators and the other in Arabic translated by the researcher especially for administrative campus staff and students. Slight variations in wording of the survey statements were implemented in order to suit each group. Colleagues revised the two versions in addition to conducting a pilot study to detect any need for changes. After receiving the comments and the results, necessary changes were made. Then the final forms were posted online and the links were distributed to teachers, administrators, and students. The first section of the survey consisted of five questions, which included 10 items in the first, 10 items in the second, 10 items in the third, 10 items in the fourth, and 8 items in the fifth. The 10 items of the first question were about what important characteristics in the EFL teacher according to their views. The second 10 items were about what they consider important practices inside the classroom by the EFL teacher. The third 10 items were about when and how the learner learns best. The fourth 10 items were about what they consider important about the institution. The last 8 items were about what they consider important during an EFL course. The participants were asked to express their view on the importance of each item based on a four-point (Essential, Important, Might Be Important, Not Important At All) Likert Scale. They were asked to select the choice which best represented their view to the statement. The second part consisted of two open-ended questions to be answered by the participants. The responses to the two open-ended questions were qualitatively analyzed. The process of tabulating, coding and categorizing was used. The full versions of the surveys are in the appendix.

\subsection{Data Collection and Procedure}

The researcher contacted the deputy dean of the PYP and the deputy dean of EFL center at the female campus of Jeddah University, in order to obtain permission to send out the survey target participants of the study. Then the surveys links were distributed. The ones who answered the surveys were 12 administrators, 22 teachers, and 195 students. The total was 229 participants. The survey was conducted at the beginning of the first semester of the academic year 2016 - 2017 and it took 25 minutes to complete. The teachers were given the English version. The learners and were provided with the Arabic version since most of them were in the first level of the EFL program, and the researcher didn't want their inefficiency in English to interfere with the results of the study. Furthermore, the administrators were also given the Arabic version upon their request.

\subsection{Data Analysis}

\subsubsection{Likert Scale Items}

The following values were assigned to responses provided for the Likert Scale items: Not at all Important $=$ less than 1.75, Might be important =between 1.75 and 2.5, Important = between 2.5 and 3.25, Essential = more than 3.25. Then the percentages and mean values for each item were calculated using SPSS.

\subsubsection{Open-ended Questions}

Participants' responses to the two open-ended questions were qualitatively analyzed. The process of tabulating, coding and categorizing was used. First, the responses were read carefully. Then they were arranged in a grid. An analysis was conducted to identify reoccurring themes. Finally, they were coded and then organized under broader categories.

\section{Findings}

\subsection{Quantitative Results}




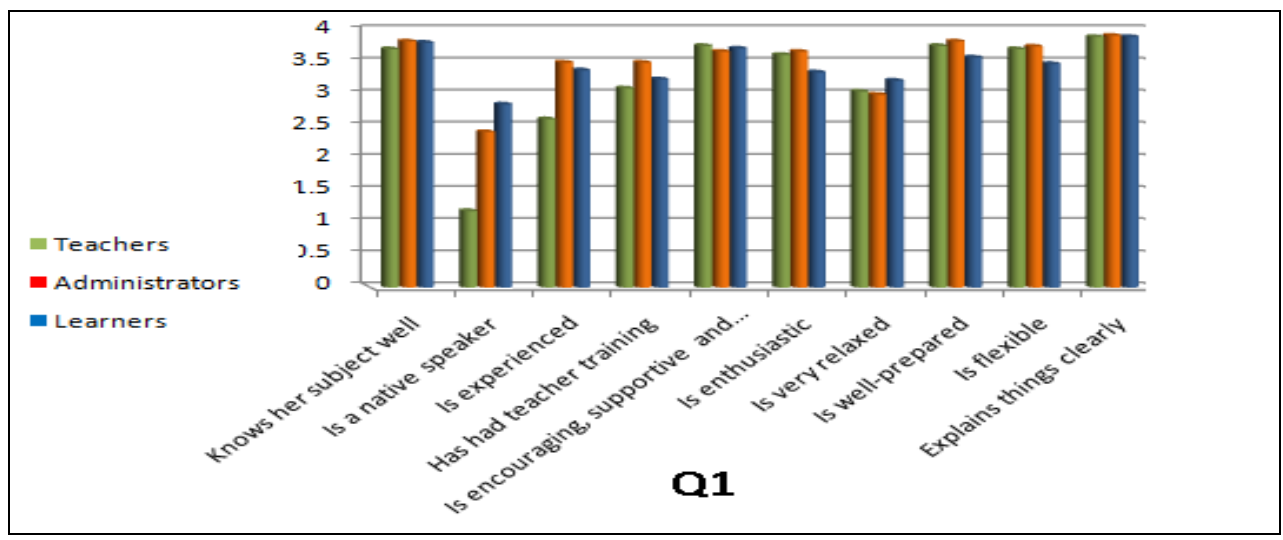

Graph 1. Comparison among the average of teachers, administrators, and students responses to the first question

For the first question about what is important in the character of the EFL teacher. Graph 1 illustrates that statement two (is a native speaker) shows a clear difference between the views of teachers and those of administrators and learners. The teachers considered it 'Not Important' to be a native speaker. The administrators saw that 'It Might Be Important'. While the students considered it 'Important'. However, $20 \%$ of students in the open-ended question 7 stated that not using Arabic in instruction is making the material difficult to understand especially for first level learners. Responses on the rest of the items ( 1 and 3 through10) fluctuated between 'Important' and 'Essential'. For statements one (knows her subject well), five (is encouraging, supportive and approachable), six (is enthusiastic), eight (is well prepared), nine (is flexible), and ten (explains things clearly), all groups' mean level of responses indicated 'Essential'. While in item number seven (is very relaxed), all groups mean level of responses indicated 'Important'. (For further details check Appendix: Statistical Tables 1, 2, and 3)

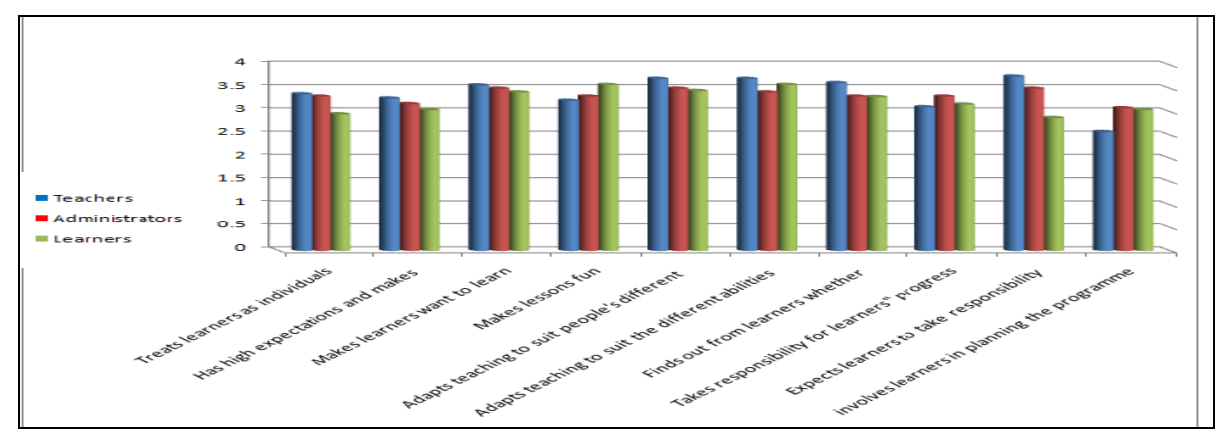

Graph 2. Comparison among the average of teachers', administrators', and students' responses to the second question

Graph 2 illustrates the mean level of items for the second question concerning the participants' view on the characteristics of an EFL teacher inside the classroom. For statements three (makes learners want to learn), four (makes lesson fun), five (adapts teaching to suit students' different ways of learning), six (adapts teaching to suit the different abilities within the class), and seven (finds out from learners whether the teaching is meeting their needs) all groups mean level indicated 'Essential'. In statement one (treats learners as individuals), teachers and administrators' mean level of responses indicated that it was 'Essential' while students' mean level indicated 'Important'. As for statement two (has high expectations and makes learners work hard), administrators and students' mean level of responses, indicated 'Important', while for teachers, it was 'Essential'. Statement number eight (takes responsibility for learners' progress) the mean level of responses showed an agreement of 'essential' for teachers and students, while administrators mean level was 'Important'. In statement nine (expects learners to take responsibility for their own progress), teachers and administrators mean level of responses was 'Essential' and the students' was 'Important'. Finally, for statement ten (involves learners in planning the program) all groups' mean level of responses indicated 'Important'. (For further details check Appendix: Statistical Tables 4, 5, and 6) 


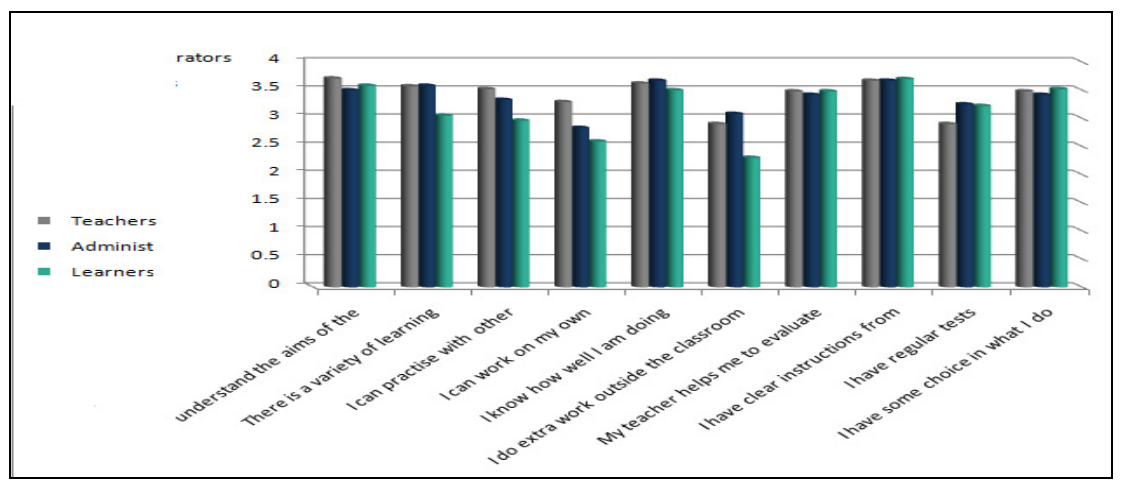

Graph 3. Comparison among the average of teachers', administrators', and students' responses to the third question

Graph 3 illustrates participants mean level of responses for question number 3 that asks about when students learn best. All groups mean level of responses indicated 'Essential' for statements one (understand the aims of the lesson and how it is helping them learn), five (they know how well they are doing), seven (the teacher helps them evaluate their own progress), eight (they have clear instruction from the teacher), and ten (students have some choice in what they do). In statement two (there is a variety of learning activities), teachers and administrators mean level of responses was 'Essential', while students' indicated 'Important'. For statement three (they can practice with other learners), and four (students can work alone) teachers and administrators' responses mean level showed 'Essential' while students' was 'Important'. Statement number six (students do extra work outside the classroom) mean level responses for teachers and administrators was 'Important' but for students it was 'Might Be Important'. Finally, for statement nine (students have regular tests) teachers and students' mean level of responses indicated 'Important' but for administrators it was 'Essential'. (For further details check Appendix: Statistical Tables 7, 8, and 9)

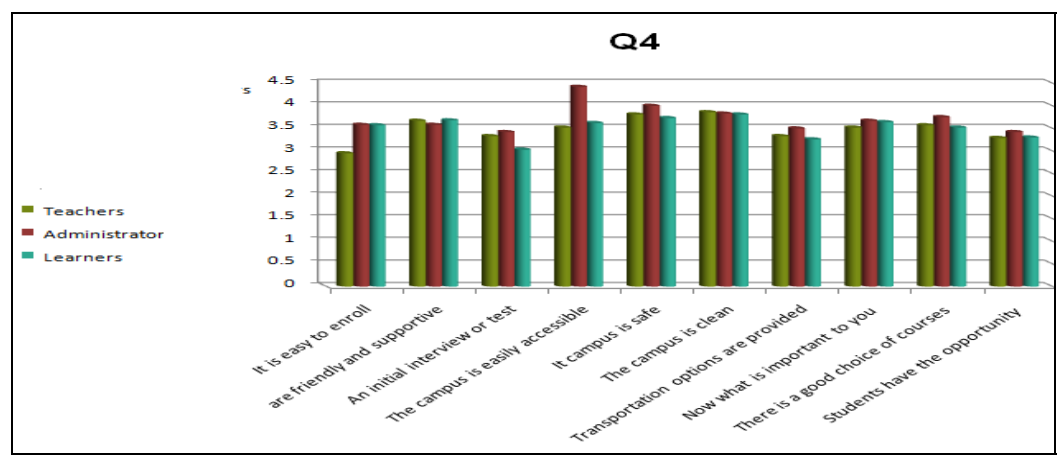

Graph 4. Comparison among the average of teachers', administrators', and students' responses to the third question

Graph 4, illustrates the mean level of participants' responses for question number 4 that asks their views of what they consider important in the institution. For statements number two (staff are friendly and supportive), four (campus is easily accessible), five (the campus is safe), six (the campus is clean), seven (transportation options are provided), eight (helpful website), nine (there is a good choice of courses and levels), and ten (opportunity to take a recognized exam), the mean level of responses of all groups was 'Essential'. However, for statement one (easy to enroll), the mean level of responses for administrators and students was 'Essential', and for teachers it was 'important'. Furthermore, for statement three (initial interview or test is used to get the student onto the right course), teachers' and administrators mean level of responses was 'Essential'. Yet students' response was 'Important' even when in question seven, 24\% think that the levels they have been assigned is not in accordance with their entrance level, which they consider very weak. (For further details check Appendix: Statistical Tables 10, 11 , and 12) 


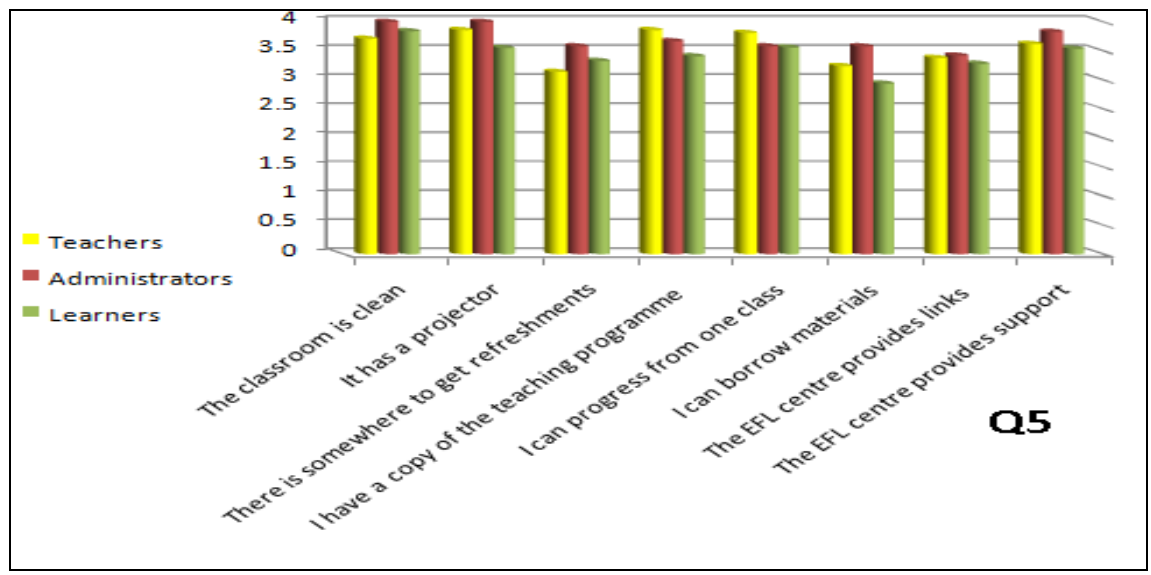

Graph 5. Comparison among the average of teachers', administrators', and students' responses to the third question

Graph 5, illustrates the mean level of participants' response for question number 5. It asks participants about their opinion of what is important in an EFL course. In statements one (clean, comfortable, and right temperature classroom), two (classroom has projector, computer, and multimedia), five (students can progress from one class to the next), six (borrow material from library), seven (course material online), and eight (support for learners with disabilities), all groups mean level of responses was 'Essential'. As for statement number three (cafeteria for refreshments and socializing with other students), the mean level of responses was administrators and students was 'Essential, while 'Important' for teachers. (For further details check Appendix: Statistical Tables 13, 14, and 15)

\subsection{Qualitative Results}

\section{Q6. Do you have any suggestions to add to the list above?}

For learners, the majority said that the program needed the inclusion of textbooks, the implementation of fair assessment tools (quizzes, timing, and feedback), revise course's difficulty to suit learners' level, train students on test taking skills, include and English club, work more on student teacher communication, and multiple teaching instructional methods and ease the pace of the instruction. The rest of the suggested the addition of summer program for weak learners and another for the gifted ones, the designation of a day for arranging papers and taking tutorial classes. While others mentioned free student services such as free printing and Xerox facilities, a bookstore, the provision of a proper student complain venue, class size, and use more Arabic in class.

For teachers, each one saw a different need from the other participants. A summary of their comments shows what they thought important and should be taken into consideration for the success of the EFL program are the following; some listed the inclusion of literature (novel, poetry, essays) in reading classes, and said that class size affects learning and teaching, and also called for the provision of a listening lab. Others wanted the administration to be more sensitive to teachers' needs (voice in policy decisions), workload, Staff/Management relationship, trust and accountability, and asked for a proper venue for student complaints.

For administrators, who were a combination of course coordinators and campus staff, the majority stated that an orientation of EFL program for the campus administrative staff is needed in order to better their contribution towards the success of the program. They also requested an EFL courses for campus staff. They see that the campus administration should attend to staff needs (job advancement/training and development/voice/ a clear and implemented job description/ trust \& accountability). For them a relax, satisfied, well developed staff is a positive addition to any program. One even added that an adequate budget does affect the campus as a whole not just the EFL program. Others mentioned that the program should provide opportunities for the gifted, outstanding students extra training courses such as summer programs inside or outside the country, and establishing and English club for students to practice their language. As for weak and struggling students, they suggested extra training courses during the summer or tutorial during the PYP. Meanwhile some saw that there should be some conformity between teacher/ administration rules, and a proper venue for students' complaints in order not to cause confusion for all, staff and students.

The consensus among the majority of the survey participants can be detected through the following mentioned points: class size, trust and accountability, and proper venue of students' complaints. Teachers and administrators 
agreed on workload. While students and administrators agreed on offering scholarship outside the country for gifted and outstanding students, or offer them extra training courses during the summer. As for weak and struggling students, they suggested extra training or tutorial courses. They also agreed on Teacher/administration rules conformity, and the establishment of an English club.

Q7. Which of the above items do you think is not applied now, and is impeding your learning experience? (...learning experience) for teachers and administrators

For learners, the majority of the students complained about the difficulty level of the quizzes, assigned materials, lack of textbooks, syllabus is unclear and confusing, block scheduling is too long, no library or assigned areas for reading or studying, the instructions are not clear, the program lacks extracurricular activities, and no English club. Thus, according to them learning has become a burden rather than fun pushing them to concentrate on grades rather than learning the language. Furthermore, they said there is no sequence in the presented material, the distributed material is too much and is costing them to print and zerox. Moreover, not all students can afford such high cost. Some complained about student / administration relationship and feel that they are not treated or served fairly, the equipment and buildings maintenance is poor and the AC is usually too cold. Others stated that they are not included in policy decisions and have no say in courses and assigned levels, students' number in class causes distraction. They added that campus rules, regulations, and implementations are not fair nor objective, which put them under the pressure of anxiety and keep them from coming to class on time, causing them to feel excluded and subsequently have no sense of belonging to the institution. In addition to that, they explained that the cafeteria does not serve healthy food nor have fair prices, adding to the already costs of the program materials.

For teachers, the majority identified the lack of equipment maintenance such as computers, projectors, $\mathrm{AC}$ and buildings as the main cause of frustration and proper lesson delivery. In addition, they stated that the classroom facilities does not allow the proper implementation of group work and innovative teaching strategies and are not suitable for students with disabilities. Furthermore, they are not clean. Some mentioned the lack of multimedia equipment, block scheduling, number of students per class, and neither listening lab nor a library is provided. Others mentioned the syllabus and the materials online as not clear for the students because of the language barrier for the beginners. They also said that there are no variety of courses for students to choose from nor are they offered the opportunity to move from one level to the next if they are found above the level they have been assigned. To them extracurricular activities are important, yet not enough time is provided in order to offer such activities. Finally, they added that the lack of inclusion in decisions causes them to feel as outsiders not as important component of the EFL center.

For administrator, the majority mentioned the workload, number of campus administrative staff vs number of students, Lack of inclusion in decisions, and equipment maintenance, and lack of sense of belonging since there are no clear job description and no implemented list of employee and students' rights and obligations. Some concentrated on the absence of a campus library, a bookstore, listening lab, and the absence of students' clubs. Others talked about the absence of clear and implemented venue for students and staff complaints, the need for extracurricular activities, and the poor internet connections.

Finally, one can see a consensus among the majority of the survey participants on the problem of equipment maintenance; block scheduling, lack of inclusion in decisions, no library, and the lack of EFL extracurricular activities. Some teachers and administrators mentioned the lack of listening lab. Furthermore, students and administrator agreed on the lack of students' clubs especially English club, and the lack of sense of belonging.

\subsection{Significant Results}

Major factors from the point of view of EFL learners in preparatory year at Jeddah University:

- $\quad$ No textbook

- $\quad$ large amount of materials and requirements

- $\quad$ Level of material / cost /distribution

- $\quad$ Level of difficulty course/quizzes

- $\quad$ No English club / No extracurricular activities

- $\quad$ No sense of belonging

- AC temperature is always high

- $\quad$ Cost of material printing

- Vague unclear instructions 
- $\quad$ Communication with administrators

Major factors from the point of view of EFL teachers in preparatory year at Jeddah University:

- Maintenance of equipment

- $\quad$ Facilities

- Student numbers per class

- Work load

- No campus library

- $\quad$ No listening lab / multimedia equipment

Major factors from the point of view of EFL administrators in preparatory year at Jeddah University:

- $\quad$ Work load (number of staff vs students)

- $\quad$ Knowledge of the EFL program

- $\quad$ Communication with EFL teachers

- $\quad$ No campus library

- No clear policies for students/staff

- Maintenance of equipment's /budget

\section{Recommendations}

- $\quad$ Adequate budget (maintenance /offering free services for students)

- Library on campus

- Orientation of the EFL program to all campus staff

- Development of social relations between the faculty / students/ administrators

- $\quad$ Proper venue for students' complaints / pay more attention to their comments and views

- $\quad$ Give students / staff a voice

- $\quad$ Provide students with test taking skills

- Train students on using the EFL center website

- Make sure students understand rules and regulations

- $\quad$ Provide a place for students to socialize (cost \& quality)

- $\quad$ Establish an English Club

- $\quad$ Provide student counseling (office hours are not used)

\section{Suggested Future Studies}

- $\quad$ English Textbook in Teaching and Learning

- The effect of anxiety on EFL students' learning

- Evaluation of English language retention of PYP students in their first year of specialized fields

- Identification and defining the variety of English Language clubs and processes of establishment and implementation (online EFL club, English Language Research club, EFL Drama club, EFL social skills club, etc.)

\section{References}

Al-Jamal, D., \& Al-Jamal, G. (2014). An Investigation of the Difficulties Faced by EFL Undergraduates in Speaking Skills. English Language Teaching, 7(1).

Al-Khairy, M. (2013a). English as a foreign language learning demotivational factors as perceived by Saudi undergraduates. European Scientific Journal, 9, 365-382.

Al-Nasser, A. (2015), Problems of English Language Acquisition in Saudi Arabia: An Exploratory-cum-remedial Study. Theory and Practice in Language Studies, 5(8), 1612-1619. https://doi.org/10.17507/tpls.0508.10

Al-Sahrqi, L., Hashim, K., \& Ahmad, P. (2014). Improving the Learning Environment at a University in Saudi Arabia: Identifying Factors That Impede or Motivate Learning. International Journal of Sciences: Basic 


\section{and Applied Research.}

Al- Alseweed, M., \& Daif-Allah, A. (2013). The Impact of an Intensive Preparatory Academic Module on Novice University Students. Journal of Arabic and Human Sciences. https://doi.org/10.12816/0009591

Alrabai, F. (2014a). A Model of Foreign Language Anxiety in the Saudi EFL Context. English Language Teaching, 7(7), 82-101. https://doi.org/10.5539/elt.v7n7p82

Alrahaili, M. (2013). Predictors of L2 attitudes and motivational intensity: A cross-sectional study in the Saudi EFL context (PhD Thesis). The University of Newcastle, Callaghan, Australia.

Alrashidi, O., \& Phan, H. (2015). Education context and English Teaching and learning in the Kingdom of Saudi Arabia: An overview. English Language Teaching, 8(25), 33-44. https://doi.org/10.5539/elt.v8n5p33

Al-Seghayer, K. (2014). The four most common constraints affecting English teaching in Saudi Arabia. International Journal of English Linguistics, 4(5), 17-26. https://doi.org/10.5539/ijel.v4n5p17

Grundtvig Learning Partnership. (2009-2011). Guidelines Teaching for Quality in Language Quality in Language Teaching for Adults, 37-40.

Elyas, T., \& Picard, M. (2010). Saudi Arabian educational history: Impacts on English language teaching. Education, Business and Society: Contemporary Middle Eastern Issues, 3(2), 136-145. https://doi.org/10.1108/17537981011047961

Rahman, M., \& Alhaisoni, E. (2013). Teaching English in Saudi Arabia: Prospects and challenges. International, 4, 112-118.

Salimi, E., \& Farsi, M. (2012). Program Evaluation of the English Language Proficiency Program for Foreign Students A Case Study: University of the East, Manila Campus. Canadian Center of Science and Education, English Language Teaching, 9(1).

Yushau, B., Omar, M. H., \& Al-Attas, H. (2006). The Effects of preparatory year courses on students' performance in first calculus courses at university: The Case of KFUPM. p. 43. METSMaC 2006. Retrieved from http://faculty.kfupm.edu.sa/math/omarmh/research_files/Yushau-B-1-METSMaC-2006.pdf

\section{Appendix: Statistical Tables}

Table 1. Teachers' responses to the first question

\begin{tabular}{|c|c|c|c|c|c|c|c|c|c|c|}
\hline \multirow{2}{*}{$\begin{array}{l}\text { Q1. What is most important } \\
\text { FOR YOU about an EFL } \\
\text { teacher in general? }\end{array}$} & \multicolumn{2}{|c|}{ Essential } & \multicolumn{2}{|c|}{ Important } & \multicolumn{2}{|c|}{$\begin{array}{l}\text { Might be } \\
\text { important }\end{array}$} & \multicolumn{2}{|c|}{$\begin{array}{l}\text { Not at all } \\
\text { important }\end{array}$} & \multirow[t]{2}{*}{ M. } & \multirow[t]{2}{*}{ Level } \\
\hline & $\mathrm{N}$ & $\%$ & $\mathrm{~N}$ & $\%$ & $\mathrm{~N}$ & $\%$ & $\mathrm{~N}$ & $\%$ & & \\
\hline Knows her subject well & 16 & 76.2 & 4 & 19 & 1 & 4.8 & 0 & 0 & 3.71 & Essential \\
\hline Is a native speaker & 0 & 0 & 0 & 0 & 4 & 19 & 17 & 81 & 1.19 & Not at all \\
\hline Is experienced & 5 & 23.8 & 5 & 23.8 & 9 & 42.9 & 2 & 9.5 & 2.62 & important \\
\hline Has had teacher training & 7 & 33.3 & 11 & 52.4 & 1 & 4.8 & 2 & 9.5 & 3.10 & important \\
\hline $\begin{array}{l}\text { Is encouraging, supportive } \\
\text { and approachable }\end{array}$ & 16 & 76.2 & 5 & 23.8 & 0 & 0 & 0 & 0 & 3.76 & Essential \\
\hline Is enthusiastic & 14 & 66.7 & 6 & 28.6 & 1 & 4.8 & 0 & 0 & 3.62 & Essential \\
\hline Is very relaxed & 8 & 38.1 & 8 & 38.1 & 3 & 14.3 & 2 & 9.5 & 3.05 & important \\
\hline Is well-prepared & 16 & 76.2 & 5 & 23.8 & 0 & 0 & 0 & 0 & 3.76 & Essential \\
\hline Is flexible & 15 & 71.4 & 6 & 28.6 & 0 & 0 & 0 & 0 & 3.71 & Essential \\
\hline Explains things clearly & 19 & 90.5 & 2 & 9.5 & 0 & 0 & 0 & 0 & 3.90 & Essential \\
\hline
\end{tabular}


Table 2. Administrators' responses to the first question

\begin{tabular}{|c|c|c|c|c|c|c|c|c|c|c|}
\hline \multirow{2}{*}{$\begin{array}{l}\text { Q1. What is most important } \\
\text { FOR YOU about an EFL } \\
\text { teacher in general? }\end{array}$} & \multicolumn{2}{|c|}{ Essential } & \multicolumn{2}{|c|}{ important } & \multicolumn{2}{|c|}{$\begin{array}{l}\text { Might be } \\
\text { important }\end{array}$} & \multicolumn{2}{|c|}{$\begin{array}{l}\text { Not at all } \\
\text { important }\end{array}$} & \multirow{2}{*}{ M. } & \multirow{2}{*}{ Level } \\
\hline & $\mathrm{N}$ & $\%$ & $\mathrm{~N}$ & $\%$ & $\mathrm{~N}$ & $\%$ & $\mathrm{~N}$ & $\%$ & & \\
\hline Knows her subject well & 10 & 83.3 & 2 & 16.7 & 0 & 0 & 0 & 0 & 3.83 & Essential \\
\hline Is a native speaker & 4 & 33.3 & 1 & 8.3 & 3 & 25 & 4 & 33.3 & 2.42 & $\begin{array}{l}\text { Might be } \\
\text { important }\end{array}$ \\
\hline Is experienced & 7 & 58.3 & 4 & 33.3 & 1 & 8.3 & 0 & 0 & 3.50 & Essential \\
\hline Has had teacher training & 7 & 58.3 & 4 & 33.3 & 1 & 8.3 & 0 & 0 & 3.50 & Essential \\
\hline $\begin{array}{l}\text { Is encouraging, supportive } \\
\text { and approachable }\end{array}$ & 8 & 66.7 & 4 & 33.3 & 0 & 0 & 0 & 0 & 3.67 & Essential \\
\hline Is enthusiastic & 8 & 66.7 & 4 & 33.3 & 0 & 0 & 0 & 0 & 3.67 & Essential \\
\hline Is very relaxed & 4 & 33.3 & 5 & 41.7 & 2 & 16.7 & 1 & 8.3 & 3.00 & important \\
\hline Is well-prepared & 10 & 83.3 & 2 & 16.7 & 0 & 0 & 0 & 0 & 3.83 & Essential \\
\hline Is flexible & 9 & 75 & 3 & 25 & 0 & 0 & 0 & 0 & 3.75 & Essential \\
\hline Explains things clearly & 11 & 91.7 & 1 & 8.3 & 0 & 0 & 0 & 0 & 3.92 & Essential \\
\hline
\end{tabular}

Table 3. Students' responses to the first question

\begin{tabular}{|c|c|c|c|c|c|c|c|c|c|c|}
\hline \multirow{2}{*}{$\begin{array}{l}\text { Q1. What is most important } \\
\text { FOR YOU about an EFL } \\
\text { teacher in general? }\end{array}$} & \multicolumn{2}{|c|}{ Essential } & \multicolumn{2}{|c|}{ important } & \multicolumn{2}{|c|}{$\begin{array}{l}\text { Might be } \\
\text { important }\end{array}$} & \multicolumn{2}{|c|}{$\begin{array}{l}\text { Not at all } \\
\text { important }\end{array}$} & \multirow[t]{2}{*}{ Mean } & \multirow[t]{2}{*}{ Level } \\
\hline & $\mathrm{N}$ & $\%$ & $\mathrm{~N}$ & $\%$ & $\mathrm{~N}$ & $\%$ & $\mathrm{~N}$ & $\%$ & & \\
\hline Knows her subject well & 162 & 83.1 & 28 & 14.4 & 5 & 2.6 & 0 & 0 & 3.81 & Essential \\
\hline Is a native speaker & 63 & 32.3 & 60 & 30.8 & 51 & 26.2 & 21 & 10.8 & 2.85 & important \\
\hline Is experienced & 104 & 53.3 & 66 & 33.8 & 21 & 10.8 & 4 & 2.1 & 3.38 & Essential \\
\hline Has had teacher training & 96 & 49.2 & 57 & 29.2 & 35 & 17.9 & 7 & 3.6 & 3.24 & Essential \\
\hline $\begin{array}{l}\text { Is encouraging, supportive } \\
\text { and approachable }\end{array}$ & 148 & 75.9 & 41 & 21 & 4 & 2.1 & 2 & 1 & 3.72 & Essential \\
\hline Is enthusiastic & 103 & 52.8 & 63 & 32.3 & 24 & 12.3 & 5 & 2.6 & 3.35 & Essential \\
\hline Is very relaxed & 102 & 52.3 & 47 & 24.1 & 32 & 16.4 & 14 & 7.2 & 3.22 & important \\
\hline Is well-prepared & 127 & 65.1 & 57 & 29.2 & 8 & 4.1 & 3 & 1.5 & 3.58 & Essential \\
\hline Is flexible & 112 & 57.4 & 68 & 34.9 & 11 & 5.6 & 4 & 2.1 & 3.48 & Essential \\
\hline Explains things clearly & 177 & 90.8 & 17 & 8.7 & 1 & 0.5 & 0 & 0 & 3.90 & Essential \\
\hline
\end{tabular}

Table 4. Teachers' responses to the second question

\begin{tabular}{|l|l|l|l|l|l|l|l|l|l|l|}
\hline \multirow{2}{*}{$\begin{array}{l}\text { Q2. In the classroom, a good } \\
\text { teacher }\end{array}$} & \multicolumn{3}{|l|}{ Essential } & \multicolumn{2}{|l|}{ important } & \multicolumn{2}{l|}{$\begin{array}{l}\text { Might be } \\
\text { important }\end{array}$} & $\begin{array}{l}\text { Not at all } \\
\text { important }\end{array}$ & M. & Level \\
\cline { 2 - 15 } & $\mathrm{N}$ & $\%$ & $\mathrm{~N}$ & $\%$ & $\mathrm{~N}$ & $\%$ & $\mathrm{~N}$ & $\%$ & & \\
\hline Treats learners as individuals & 10 & 47.6 & 9 & 42.9 & 2 & 9.5 & 0 & 0 & 3.38 & Essential \\
\hline Has high expectations and & 7 & 33.3 & 13 & 61.9 & 1 & 4.8 & 0 & 0 & 3.29 & Essential \\
\hline Makes learners want to learn & 12 & 57.1 & 9 & 42.9 & 0 & 0 & 0 & 0 & 3.57 & Essential \\
\hline
\end{tabular}




\begin{tabular}{|l|l|l|l|l|l|l|l|l|l|l|}
\hline Makes lessons fun & 9 & 42.9 & 8 & 38.1 & 4 & 19 & 0 & 0 & 3.24 & \\
\hline $\begin{array}{l}\text { Adapts teaching to suit people's } \\
\text { different ways of learning }\end{array}$ & 15 & 71.4 & 6 & 28.6 & 0 & 0 & 0 & 0 & 3.71 & Essential \\
\hline $\begin{array}{l}\text { Adapts teaching to suit the } \\
\text { different abilities within the } \\
\text { class }\end{array}$ & 15 & 71.4 & 6 & 28.6 & 0 & 0 & 0 & 0 & 3.71 & Essential \\
\hline $\begin{array}{l}\text { Finds out from learners } \\
\text { whether the teaching is meeting } \\
\text { their needs }\end{array}$ & 14 & 66.7 & 6 & 28.6 & 1 & 4.8 & 0 & 0 & 3.62 & Essential \\
\hline $\begin{array}{l}\text { Takes responsibility for } \\
\text { learners" progress }\end{array}$ & 7 & 33.3 & 10 & 47.6 & 3 & 14.3 & 1 & 4.8 & 3.10 & Important \\
\hline $\begin{array}{l}\text { Expects learners to take } \\
\text { responsibility for their own }\end{array}$ & 16 & 76.2 & 5 & 23.8 & 0 & 0 & 0 & 0 & 3.76 & Essential \\
\hline $\begin{array}{l}\text { involves learners in planning the } \\
\text { program }\end{array}$ & 4 & 19 & 4 & 19 & 13 & 61.9 & 0 & 0 & 2.57 & Important \\
\hline
\end{tabular}

Table 5. Administrators' responses to the second question

\begin{tabular}{|c|c|c|c|c|c|c|c|c|c|c|}
\hline \multirow[t]{2}{*}{$\begin{array}{l}\text { Q2. In the classroom, a good } \\
\text { teacher }\end{array}$} & \multicolumn{2}{|c|}{ Essential } & \multicolumn{2}{|c|}{ important } & \multicolumn{2}{|c|}{$\begin{array}{l}\text { Might be } \\
\text { Important }\end{array}$} & \multicolumn{2}{|c|}{$\begin{array}{l}\text { Not at all } \\
\text { important }\end{array}$} & \multirow[t]{2}{*}{ M. } & \multirow[t]{2}{*}{ Level } \\
\hline & $\mathrm{N}$ & $\%$ & $\mathrm{~N}$ & $\%$ & $\mathrm{~N}$ & $\%$ & $\mathrm{~N}$ & $\%$ & & \\
\hline Treats learners as individuals & 6 & 50 & 5 & 41.7 & 0 & 0 & 1 & 8.3 & 3.33 & Essential \\
\hline $\begin{array}{l}\text { Has high expectations and } \\
\text { makes learners work hard }\end{array}$ & 5 & 41.7 & 5 & 41.7 & 1 & 8.3 & 1 & 8.3 & 3.17 & Important \\
\hline Makes learners want to learn & 7 & 58.3 & 4 & 33.3 & 1 & 8.3 & 0 & 0 & 3.50 & Essential \\
\hline Makes lessons fun & 5 & 41.7 & 6 & 50 & 1 & 8.3 & 0 & 0 & 3.33 & Essential \\
\hline $\begin{array}{lccc}\text { Adapts } & \text { teaching } & \text { to } & \text { suit } \\
\text { people's } & \text { different } & \text { ways } & \text { of } \\
\text { learning } & & & \end{array}$ & 7 & 58.3 & 4 & 33.3 & 1 & 8.3 & 0 & 0 & 3.50 & Essential \\
\hline $\begin{array}{l}\text { Adapts teaching to suit the } \\
\text { different abilities within the } \\
\text { class }\end{array}$ & 6 & 50 & 5 & 41.7 & 1 & 8.3 & 0 & 0 & 3.42 & Essential \\
\hline $\begin{array}{l}\text { Finds out from learners } \\
\text { whether the teaching is meeting } \\
\text { their needs }\end{array}$ & 5 & 41.7 & 6 & 50 & 1 & 8.3 & 0 & 0 & 3.33 & Essential \\
\hline 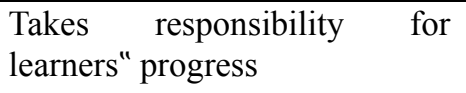 & 4 & 33.3 & 8 & 66.7 & 0 & 0 & 0 & 0 & 3.33 & Essential \\
\hline $\begin{array}{l}\text { Expects learners to take } \\
\text { responsibility for their own }\end{array}$ & 7 & 58.3 & 4 & 33.3 & 1 & 8.3 & 0 & 0 & 3.50 & Essential \\
\hline $\begin{array}{l}\text { involves learners in planning } \\
\text { the program }\end{array}$ & 2 & 16.7 & 9 & 75 & 1 & 8.3 & 0 & 0 & 3.08 & Important \\
\hline
\end{tabular}


Table 6. Students' responses to the second question

\begin{tabular}{|c|c|c|c|c|c|c|c|c|c|c|}
\hline \multirow[t]{2}{*}{$\begin{array}{l}\text { Q2. In the classroom, a good } \\
\text { teacher }\end{array}$} & \multicolumn{2}{|c|}{ Essential } & \multicolumn{2}{|c|}{ important } & \multicolumn{2}{|c|}{$\begin{array}{l}\text { Might be } \\
\text { important }\end{array}$} & \multicolumn{2}{|c|}{$\begin{array}{l}\text { Not at all } \\
\text { important }\end{array}$} & \multirow[t]{2}{*}{ M. } & \multirow[t]{2}{*}{ Level } \\
\hline & $\mathrm{N}$ & $\%$ & $\mathrm{~N}$ & $\%$ & $\mathrm{~N}$ & $\%$ & $\mathrm{~N}$ & $\%$ & & \\
\hline Treats learners as individuals & 72 & 36.9 & 63 & 32.3 & 38 & 19.5 & 22 & 11.3 & 2.95 & important \\
\hline $\begin{array}{l}\text { Has high expectations and } \\
\text { makes learners work hard }\end{array}$ & 64 & 32.8 & 84 & 43.1 & 37 & 19 & 10 & 5.1 & 3.04 & important \\
\hline Makes learners want to learn & 105 & 53.8 & 71 & 36.4 & 15 & 7.7 & 4 & 2.1 & 3.42 & Essential \\
\hline Makes lessons fun & 135 & 69.2 & 41 & 21 & 17 & 8.7 & 2 & 1 & 3.58 & Essential \\
\hline $\begin{array}{l}\text { Adapts teaching to suit people's } \\
\text { different ways of learning }\end{array}$ & 112 & 57.4 & 59 & 30.3 & 23 & 11.8 & 1 & 0.5 & 3.45 & Essential \\
\hline $\begin{array}{l}\text { Adapts teaching to suit the } \\
\text { different abilities within the } \\
\text { class }\end{array}$ & 127 & 71.4 & 55 & 28.2 & 13 & 6.7 & 0 & 0 & 3.58 & Essential \\
\hline $\begin{array}{l}\text { Finds out from learners whether } \\
\text { the teaching is meeting their } \\
\text { needs }\end{array}$ & 98 & 50.3 & 67 & 34.4 & 25 & 12.8 & 5 & 2.6 & 3.32 & Essential \\
\hline $\begin{array}{l}\text { Takes responsibility for } \\
\text { learners' progress }\end{array}$ & 84 & 43.1 & 67 & 34.4 & 35 & 17.9 & 9 & 4.6 & 3.16 & important \\
\hline $\begin{array}{l}\text { Expects learners to take } \\
\text { responsibility for their own }\end{array}$ & 51 & 26.2 & 80 & 41 & 52 & 26.7 & 12 & 6.2 & 2.87 & important \\
\hline $\begin{array}{l}\text { involves learners in planning } \\
\text { the program }\end{array}$ & 74 & 37.9 & 65 & 33.3 & 45 & 23.1 & 11 & 5.6 & 3.04 & important \\
\hline
\end{tabular}

Table 7. Teachers' responses to the third question

\begin{tabular}{|c|c|c|c|c|c|c|c|c|c|c|}
\hline \multirow[t]{2}{*}{ Q3. I learn best when... } & \multicolumn{2}{|c|}{ Essential } & \multicolumn{2}{|c|}{ important } & \multicolumn{2}{|c|}{$\begin{array}{l}\text { Might be } \\
\text { important }\end{array}$} & \multicolumn{2}{|c|}{$\begin{array}{l}\text { Not at all } \\
\text { important }\end{array}$} & \multirow[t]{2}{*}{ M. } & \multirow[t]{2}{*}{ Level } \\
\hline & $\mathrm{N}$ & $\%$ & $\mathrm{~N}$ & $\%$ & $\mathrm{~N}$ & $\%$ & $\mathrm{~N}$ & $\%$ & & \\
\hline $\begin{array}{l}\text { understand the aims of the } \\
\text { lesson and how it is helping me } \\
\text { learn }\end{array}$ & 15 & 71.4 & 6 & 28.6 & 0 & 0 & 0 & 0 & 3.71 & Essential \\
\hline $\begin{array}{l}\text { There is a variety of learning } \\
\text { Activities }\end{array}$ & 14 & 66.7 & 5 & 23.8 & 2 & 9.5 & 0 & 0 & 3.57 & Essential \\
\hline $\begin{array}{l}\text { I can practice with other } \\
\text { Learners }\end{array}$ & 12 & 57.1 & 8 & 38.1 & 1 & 4.8 & 0 & 0 & 3.52 & Essential \\
\hline I can work on my own & 9 & 42.9 & 10 & 47.6 & 1 & 4.8 & 1 & 4.8 & 3.29 & Essential \\
\hline I know how well I am doing & 13 & 61.9 & 8 & 38.1 & 0 & 0 & 0 & 0 & 3.62 & Essential \\
\hline $\begin{array}{l}\text { I do extra work outside the } \\
\text { classroom }\end{array}$ & 3 & 14.3 & 13 & 61.9 & 5 & 23.8 & 0 & 0 & 2.90 & Important \\
\hline $\begin{array}{l}\text { My teacher helps me to evaluate } \\
\text { my own progress }\end{array}$ & 11 & 52.4 & 9 & 42.9 & 1 & 4.8 & 0 & 0 & 3.48 & Essential \\
\hline $\begin{array}{l}\text { I have clear instructions from } \\
\text { my teacher }\end{array}$ & 14 & 66.7 & 7 & 33.3 & 0 & 0 & 0 & 0 & 3.67 & Essential \\
\hline
\end{tabular}




\begin{tabular}{|l|l|l|l|l|l|l|l|l|l|l|}
\hline I have regular tests & 4 & 19 & 11 & 52.4 & 6 & 28.6 & 0 & 0 & 2.90 & Important \\
\hline I have some choice in what I do & 12 & 57.1 & 7 & 33.3 & 2 & 9.5 & 0 & 0 & 3.48 & Essential \\
\hline
\end{tabular}

Table 8. Administrators' responses to the third question

\begin{tabular}{|c|c|c|c|c|c|c|c|c|c|c|}
\hline \multirow[t]{2}{*}{ Q3. I learn best when... } & \multicolumn{2}{|c|}{ Essential } & \multicolumn{2}{|c|}{ important } & \multicolumn{2}{|c|}{$\begin{array}{l}\text { Might be } \\
\text { important }\end{array}$} & \multicolumn{2}{|c|}{$\begin{array}{l}\text { Not at all } \\
\text { important }\end{array}$} & \multirow[t]{2}{*}{ M. } & \multirow[t]{2}{*}{ Level } \\
\hline & $\mathrm{N}$ & $\%$ & $\mathrm{~N}$ & $\%$ & $\mathrm{~N}$ & $\%$ & $\mathrm{~N}$ & $\%$ & & \\
\hline $\begin{array}{l}\text { understand the aims of the } \\
\text { lesson and how it is helping } \\
\text { me learn }\end{array}$ & 7 & 58.3 & 4 & 33.3 & 1 & 8.3 & 0 & 0 & 3.50 & Essential \\
\hline $\begin{array}{l}\text { There is a variety of learning } \\
\text { Activities }\end{array}$ & 7 & 58.3 & 5 & 41.7 & 0 & 0 & 0 & 0 & 3.58 & Essential \\
\hline $\begin{array}{l}\text { I can practice with other } \\
\text { Learners }\end{array}$ & 5 & 41.7 & 6 & 50 & 1 & 8.3 & 0 & 0 & 3.33 & Essential \\
\hline I can work on my own & 2 & 16.7 & 7 & 58.3 & 2 & 16.7 & 1 & 8.3 & 2.83 & Essential \\
\hline I know how well I am doing & 8 & 66.7 & 4 & 33.3 & 0 & 0 & 0 & 0 & 3.67 & Essential \\
\hline $\begin{array}{l}\text { I do extra work outside the } \\
\text { classroom }\end{array}$ & 5 & 41.7 & 3 & 25 & 4 & 33.3 & 0 & 0 & 3.08 & Important \\
\hline $\begin{array}{l}\text { My teacher helps me to } \\
\text { evaluate my own progress }\end{array}$ & 6 & 50 & 5 & 41.7 & 1 & 8.3 & 0 & 0 & 3.42 & Essential \\
\hline $\begin{array}{l}\text { I have clear instructions from } \\
\text { my teacher }\end{array}$ & 8 & 66.7 & 4 & 33.3 & 0 & 0 & 0 & 0 & 3.67 & Essential \\
\hline I have regular tests & 5 & 41.7 & 5 & 41.7 & 2 & 16.7 & 0 & 0 & 3.25 & Essential \\
\hline $\begin{array}{l}\text { I have some choice in what I } \\
\text { do }\end{array}$ & 6 & 50 & 5 & 41.7 & 1 & 8.3 & 0 & 0 & 3.42 & Essential \\
\hline
\end{tabular}

Table 9. Students' responses to the third question

\begin{tabular}{|c|c|c|c|c|c|c|c|c|c|c|}
\hline \multirow[t]{2}{*}{ Q3. I learn best when... } & \multicolumn{2}{|c|}{ Essential } & \multicolumn{2}{|c|}{ important } & \multicolumn{2}{|c|}{$\begin{array}{l}\text { Might be } \\
\text { important }\end{array}$} & \multicolumn{2}{|c|}{$\begin{array}{l}\text { Not at all } \\
\text { important }\end{array}$} & \multirow[t]{2}{*}{ M. } & \multirow[t]{2}{*}{ Level } \\
\hline & $\mathrm{N}$ & $\%$ & $\mathrm{~N}$ & $\%$ & $\mathrm{~N}$ & $\%$ & $\mathrm{~N}$ & $\%$ & & \\
\hline $\begin{array}{l}\text { understand the aims of the } \\
\text { lesson and how it is helping } \\
\text { me learn }\end{array}$ & 132 & 67.7 & 48 & 24.6 & 12 & 6.2 & 3 & 1.5 & 3.58 & Essential \\
\hline $\begin{array}{l}\text { There is a variety of learning } \\
\text { Activities }\end{array}$ & 76 & 39 & 66 & 33.8 & 40 & 20.5 & 13 & 6.7 & 3.05 & important \\
\hline $\begin{array}{l}\text { I can practice with other } \\
\text { Learners }\end{array}$ & 69 & 35.4 & 66 & 33.8 & 44 & 22.6 & 16 & 8.2 & 2.96 & important \\
\hline I can work on my own & 41 & 21 & 63 & 32.3 & 62 & 31.8 & 29 & 14.9 & 2.59 & important \\
\hline I know how well I am doing & 116 & 59.5 & 63 & 32.3 & 14 & 7.2 & 2 & 1 & 3.50 & Essential \\
\hline $\begin{array}{l}\text { I do extra work outside the } \\
\text { classroom }\end{array}$ & 38 & 19.5 & 36 & 18.5 & 67 & 34.4 & 54 & 27.7 & 2.30 & $\begin{array}{l}\text { Might be } \\
\text { important }\end{array}$ \\
\hline $\begin{array}{l}\text { My teacher helps me to } \\
\text { evaluate my own progress }\end{array}$ & 116 & 59.5 & 57 & 29.2 & 21 & 10.8 & 1 & 0.5 & 3.48 & Essential \\
\hline $\begin{array}{l}\text { I have clear instructions from } \\
\text { my teacher }\end{array}$ & 145 & 74.4 & 42 & 21.5 & 7 & 3.6 & 1 & 0.5 & 3.70 & Essential \\
\hline
\end{tabular}




\begin{tabular}{|l|l|l|l|l|l|l|l|l|l|l|}
\hline I have regular tests & 91 & 46.7 & 61 & 31.3 & 37 & 19 & 6 & 3.1 & 3.22 & important \\
\hline $\begin{array}{l}\text { I have some choice in what I } \\
\text { do }\end{array}$ & 119 & 61 & 60 & 30.8 & 14 & 7.2 & 2 & 1 & 3.52 & Essential \\
\hline
\end{tabular}

Table 10. Teachers' responses to the fourth question

\begin{tabular}{|c|c|c|c|c|c|c|c|c|c|c|}
\hline \multirow{2}{*}{$\begin{array}{l}\text { Q4. Now what is important to } \\
\text { you about the institution? }\end{array}$} & \multicolumn{2}{|c|}{ Essential } & \multicolumn{2}{|c|}{ important } & \multicolumn{2}{|c|}{$\begin{array}{l}\text { Might be } \\
\text { Important }\end{array}$} & \multicolumn{2}{|c|}{$\begin{array}{l}\text { Not at all } \\
\text { important }\end{array}$} & \multirow[t]{2}{*}{ M. } & \multirow[t]{2}{*}{ Level } \\
\hline & $\mathrm{N}$ & $\%$ & $\mathrm{~N}$ & $\%$ & $\mathrm{~N}$ & $\%$ & $\mathrm{~N}$ & $\%$ & & \\
\hline It is easy to enroll & 6 & 28.6 & 9 & 42.9 & 5 & 23.8 & 1 & 4.8 & 2.95 & Important \\
\hline are friendly and supportive & 15 & 71.4 & 5 & 23.8 & 1 & 4.8 & 0 & 0 & 3.67 & \\
\hline $\begin{array}{l}\text { An initial interview or test is } \\
\text { used to get me onto the right } \\
\text { course }\end{array}$ & 13 & 61.9 & 3 & 14.3 & 4 & 19 & 1 & 4.8 & 3.33 & Essential \\
\hline The campus is easily accessible & 14 & 66.7 & 4 & 19 & 3 & 14.3 & 0 & 0 & 3.52 & Essential \\
\hline It campus is safe & 17 & 81.0 & 4 & 19 & 0 & 0 & 0 & 0 & 3.81 & Essential \\
\hline The campus is clean & 18 & 85.7 & 3 & 14.3 & 0 & 0 & 0 & 0 & 3.86 & Essential \\
\hline $\begin{array}{lll}\text { Transportation } & \text { options } & \text { are } \\
\text { provided } & & \end{array}$ & 10 & 47.6 & 8 & 38.1 & 3 & 14.3 & 0 & 0 & 3.33 & Essential \\
\hline $\begin{array}{l}\text { Now what is important to you } \\
\text { about the institution? [There is a } \\
\text { helpful website }\end{array}$ & 12 & 57.1 & 8 & 38.1 & 1 & 4.8 & 0 & 0 & 3.52 & Essential \\
\hline $\begin{array}{l}\text { There is a good choice of } \\
\text { courses and levels }\end{array}$ & 14 & 66.7 & 5 & 23.8 & 2 & 9.5 & 0 & 0 & 3.57 & Essential \\
\hline $\begin{array}{l}\text { Students have the opportunity to } \\
\text { take a recognized exam }\end{array}$ & 9 & 42.9 & 9 & 42.9 & 3 & 14.3 & 0 & 0 & 3.29 & Essential \\
\hline
\end{tabular}

Table 11. Administrators' responses to the fourth question

\begin{tabular}{|c|c|c|c|c|c|c|c|c|c|c|}
\hline \multirow{2}{*}{$\begin{array}{l}\text { Q4. Now what is important to } \\
\text { you about the institution? }\end{array}$} & \multicolumn{2}{|c|}{ Essential } & \multicolumn{2}{|c|}{ important } & \multicolumn{2}{|c|}{$\begin{array}{l}\text { Might be } \\
\text { Important }\end{array}$} & \multicolumn{2}{|c|}{$\begin{array}{l}\text { Not at all } \\
\text { important }\end{array}$} & \multirow[t]{2}{*}{ M. } & \multirow[t]{2}{*}{ Level } \\
\hline & $\mathrm{N}$ & $\%$ & $\mathrm{~N}$ & $\%$ & $\mathrm{~N}$ & $\%$ & $\mathrm{~N}$ & $\%$ & & \\
\hline It is easy to enroll & 7 & 58.3 & 5 & 41.7 & 0 & 0 & 0 & 0 & 3.58 & Essential \\
\hline are friendly and supportive & 8 & 66.7 & 3 & 25 & 1 & 8.3 & 0 & 0 & 3.58 & Essential \\
\hline $\begin{array}{l}\text { An initial interview or test is } \\
\text { used to get me onto the right } \\
\text { course }\end{array}$ & 6 & 50 & 5 & 41.7 & 1 & 8.3 & 0 & 0 & 3.42 & Essential \\
\hline The campus is easily accessible & 8 & 66.7 & 6 & 50 & 1 & 8.3 & 1 & 8.3 & 4.42 & Essential \\
\hline The campus is safe & 12 & 100 & 0 & 0 & 0 & 0 & 0 & 0 & 4.00 & Essential \\
\hline The campus is clean & 10 & 83.3 & 2 & 16.7 & 0 & 0 & 0 & 0 & 3.83 & Essential \\
\hline $\begin{array}{lll}\begin{array}{l}\text { Transportation } \\
\text { provided }\end{array} & \text { options } & \text { are } \\
& & \end{array}$ & 6 & 50 & 6 & 50 & 0 & 0 & 0 & 0 & 3.50 & Essential \\
\hline $\begin{array}{l}\text { Now what is important to you } \\
\text { about the institution? [There is a } \\
\text { helpful website }\end{array}$ & 9 & 75 & 2 & 16.7 & 1 & 8.3 & 0 & 0 & 3.67 & Essential \\
\hline
\end{tabular}




\begin{tabular}{|l|l|l|l|l|l|l|l|l|l|l|}
\hline $\begin{array}{l}\text { There is a good choice of courses } \\
\text { and levels }\end{array}$ & 9 & 75 & 3 & 25 & 0 & 0 & 0 & 0 & 3.75 & Essential \\
\hline $\begin{array}{l}\text { Students have the opportunity to } \\
\text { take a recognized exam }\end{array}$ & 6 & 50 & 5 & 41.7 & 1 & 8.3 & 0 & 0 & 3.42 & Essential \\
\hline
\end{tabular}

Table 12. Students' responses to the fourth question

\begin{tabular}{|c|c|c|c|c|c|c|c|c|c|c|}
\hline \multirow{2}{*}{$\begin{array}{l}\text { Q4. Now what is important to } \\
\text { you about the institution? }\end{array}$} & \multicolumn{2}{|c|}{ Essential } & \multicolumn{2}{|c|}{ important } & \multicolumn{2}{|c|}{$\begin{array}{l}\text { Might be } \\
\text { Important }\end{array}$} & \multicolumn{2}{|c|}{$\begin{array}{l}\text { Not at all } \\
\text { important }\end{array}$} & \multirow[t]{2}{*}{ M. } & \multirow[t]{2}{*}{ Level } \\
\hline & $\mathrm{N}$ & $\%$ & $\mathrm{~N}$ & $\%$ & $\mathrm{~N}$ & $\%$ & $\mathrm{~N}$ & $\%$ & & \\
\hline It is easy to enroll & 136 & 69.7 & 41 & 21 & 12 & 6.2 & 6 & 3.1 & 3.57 & Essential \\
\hline are friendly and supportive & 143 & 73.3 & 42 & 21.5 & 9 & 4.6 & 1 & 0.5 & 3.68 & Essential \\
\hline $\begin{array}{l}\text { An initial interview or test is } \\
\text { used to get me onto the right } \\
\text { course }\end{array}$ & 85 & 43.6 & 52 & 26.7 & 36 & 18.5 & 22 & 11.3 & 3.03 & mportant \\
\hline $\begin{array}{l}\text { The campus is easily } \\
\text { accessible }\end{array}$ & 135 & 69.2 & 47 & 24.1 & 11 & 5.6 & 2 & 1 & 3.62 & Essential \\
\hline It campus is safe & 154 & 79 & 32 & 16.4 & 7 & 3.6 & 2 & 1 & 3.73 & Essential \\
\hline The campus is clean & 162 & 83.1 & 30 & 15.4 & 1 & 0.5 & 2 & 1 & 3.81 & Essential \\
\hline $\begin{array}{l}\text { Transportation options are } \\
\text { provided }\end{array}$ & 106 & 54.4 & 44 & 22.6 & 35 & 17.9 & 10 & 5.1 & 3.26 & Essential \\
\hline $\begin{array}{l}\text { Now what is important to you } \\
\text { about the institution? [There is } \\
\text { a helpful website }\end{array}$ & 144 & 73.8 & 33 & 16.9 & 16 & 8.2 & 2 & 1 & 3.64 & Essential \\
\hline $\begin{array}{l}\text { There is a good choice of } \\
\text { courses and levels }\end{array}$ & 122 & 62.6 & 55 & 28.2 & 16 & 8.2 & 2 & 1 & 3.52 & Essential \\
\hline $\begin{array}{l}\text { Students have the opportunity } \\
\text { to take a recognized exam }\end{array}$ & 99 & 50.8 & 65 & 33.3 & 21 & 10.8 & 10 & 5.1 & 3.30 & Essential \\
\hline
\end{tabular}

Table 13. Teachers' responses to the fifth question

\begin{tabular}{|c|c|c|c|c|c|c|c|c|c|c|}
\hline \multirow[t]{2}{*}{ Q5.. And during your course? } & \multicolumn{2}{|c|}{ Essential } & \multicolumn{2}{|c|}{ important } & \multicolumn{2}{|c|}{$\begin{array}{l}\text { Might be } \\
\text { important }\end{array}$} & \multicolumn{2}{|c|}{$\begin{array}{l}\text { Not at all } \\
\text { important }\end{array}$} & \multirow[t]{2}{*}{ M. } & \multirow[t]{2}{*}{ Level } \\
\hline & $\mathrm{N}$ & $\%$ & $\mathrm{~N}$ & $\%$ & $\mathrm{~N}$ & $\%$ & $\mathrm{~N}$ & $\%$ & & \\
\hline $\begin{array}{l}\text { The classroom is clean, } \\
\text { comfortable and the right } \\
\text { temperature }\end{array}$ & 16 & 76.2 & 4 & 19 & 1 & 4.8 & 0 & 0 & 3.71 & Essential \\
\hline $\begin{array}{l}\text { It has a projector, computer and } \\
\text { multimedia equipment }\end{array}$ & 18 & 85.7 & 3 & 14.3 & 0 & 0 & 0 & 0 & 3.86 & Essential \\
\hline $\begin{array}{l}\text { There is somewhere to get } \\
\text { refreshments and meet other } \\
\text { learners socially }\end{array}$ & 11 & 52.4 & 4 & 19 & 5 & 23.8 & 0 & 0 & 3.14 & important \\
\hline $\begin{array}{l}\text { I have a copy of the teaching } \\
\text { program and know what we are } \\
\text { going to cover }\end{array}$ & 18 & 85.7 & 3 & 14.3 & 0 & 0 & 0 & 0 & 3.86 & Essential \\
\hline $\begin{array}{l}\text { I can progress from one class to } \\
\text { the next }\end{array}$ & 17 & 81.0 & 4 & 19 & 0 & 0 & 0 & 0 & 3.81 & Essential \\
\hline
\end{tabular}




\begin{tabular}{|l|l|l|l|l|l|l|l|l|l|l|}
\hline $\begin{array}{l}\text { I can borrow materials (e.g. } \\
\text { books/CD/DVD) } \\
\text { Through library or loan }\end{array}$ & 9 & 42.9 & 8 & 38.1 & 4 & 19 & 0 & 0 & 3.24 & important \\
\hline $\begin{array}{l}\text { The EFL Centre provides links to } \\
\text { materials online }\end{array}$ & 11 & 52.4 & 7 & 33.3 & 3 & 14.3 & 0 & 0 & 3.38 & Essential \\
\hline $\begin{array}{l}\text { The EFL Centre provides support } \\
\text { for learners with disabilities }\end{array}$ & 15 & 71.4 & 4 & 19 & 2 & 9.5 & 0 & 0 & 3.62 & Essential \\
\hline
\end{tabular}

Table 14. Administrators' responses to the fifth question

\begin{tabular}{|c|c|c|c|c|c|c|c|c|c|c|}
\hline \multirow[t]{2}{*}{ Q5.. And during your course? } & \multicolumn{2}{|c|}{ Essential } & \multicolumn{2}{|c|}{ important } & \multicolumn{2}{|c|}{$\begin{array}{l}\text { Might be } \\
\text { important }\end{array}$} & \multicolumn{2}{|c|}{$\begin{array}{l}\text { Not at all } \\
\text { important }\end{array}$} & \multirow[t]{2}{*}{ M. } & \multirow[t]{2}{*}{ Level } \\
\hline & $\mathrm{N}$ & $\%$ & $\mathrm{~N}$ & $\%$ & $\mathrm{~N}$ & $\%$ & $\mathrm{~N}$ & $\%$ & & \\
\hline $\begin{array}{l}\text { The classroom is clean, } \\
\text { comfortable and the right } \\
\text { temperature }\end{array}$ & 12 & 100 & 0 & 0 & 0 & 0 & 0 & 0 & 4.00 & Essential \\
\hline $\begin{array}{l}\text { It has a projector, computer and } \\
\text { multimedia equipment }\end{array}$ & 12 & 100 & 0 & 0 & 0 & 0 & 0 & 0 & 4.00 & Essential \\
\hline $\begin{array}{l}\text { There is somewhere to get } \\
\text { refreshments and meet other } \\
\text { learners socially }\end{array}$ & 7 & 58.3 & 5 & 41.7 & 0 & 0 & 0 & 0 & 3.58 & Essential \\
\hline & 9 & 75 & 2 & 16.7 & 1 & 8.3 & 0 & 0 & 3.67 & Essential \\
\hline $\begin{array}{l}\text { I can progress from one class to the } \\
\text { next }\end{array}$ & 7 & 58.3 & 5 & 41.7 & 0 & 0 & 0 & 0 & 3.58 & Essential \\
\hline $\begin{array}{l}\text { I can borrow materials (e.g. } \\
\text { books/CD/DVD) through library or } \\
\text { loan }\end{array}$ & 7 & 58.3 & 5 & 41.7 & 0 & 0 & 0 & 0 & 3.58 & Essential \\
\hline $\begin{array}{l}\text { The Centre provides links to } \\
\text { materials online }\end{array}$ & 7 & 58.3 & 3 & 25 & 2 & 16.7 & 0 & 0 & 3.42 & Essential \\
\hline $\begin{array}{l}\text { The Centre provides support for } \\
\text { learners with disabilities }\end{array}$ & 10 & 83.3 & 2 & 16.7 & 0 & 0 & 0 & 0 & 3.83 & Essential \\
\hline
\end{tabular}

Table 15. Students' responses to the fifth question

\begin{tabular}{|l|l|l|l|l|l|l|l|l|l|l|}
\hline \multirow{2}{*}{ Q5.. And during your course? } & \multicolumn{2}{|l|}{ Essential } & \multicolumn{2}{|l|}{ important } & \multicolumn{2}{l|}{$\begin{array}{l}\text { Might be } \\
\text { important }\end{array}$} & \multicolumn{2}{l|}{$\begin{array}{l}\text { Not at all } \\
\text { important }\end{array}$} & \multirow{2}{*}{ M. } & Level \\
\cline { 2 - 12 } & $\mathrm{N}$ & $\%$ & $\mathrm{~N}$ & $\%$ & $\mathrm{~N}$ & $\%$ & $\mathrm{~N}$ & $\%$ & \\
\hline $\begin{array}{l}\text { The classroom is clean, } \\
\text { comfortable and the right } \\
\text { temperature }\end{array}$ & 167 & 85.6 & 25 & 12.8 & 2 & 1 & 1 & 0.5 & 3.84 & Essential \\
\hline $\begin{array}{l}\text { It has a projector, computer } \\
\text { and } \\
\text { multimedia equipment }\end{array}$ & 125 & 64.1 & 54 & 27.7 & 14 & 7.2 & 2 & 1 & 3.55 & Essential \\
\hline $\begin{array}{l}\text { There is somewhere to get } \\
\text { refreshments and meet other } \\
\text { learners socially }\end{array}$ & 99 & 50.8 & 66 & 33.8 & 26 & 13.3 & 4 & 2.1 & 3.33 & Essential \\
\hline
\end{tabular}




\begin{tabular}{|l|l|l|l|l|l|l|l|l|l|l|}
\hline $\begin{array}{l}\text { I have a copy of the teaching } \\
\text { program and know what we } \\
\text { are going to cover }\end{array}$ & 118 & 60.5 & 48 & 24.6 & 19 & 9.7 & 10 & 5.1 & 3.41 & Essential \\
\hline $\begin{array}{l}\text { I can progress from one class } \\
\text { to the next }\end{array}$ & 130 & 66.7 & 49 & 25.1 & 11 & 5.6 & 5 & 2.6 & 3.56 & Essential \\
\hline $\begin{array}{l}\text { I can borrow materials (e.g. } \\
\text { books/CD/DVD) } \\
\text { Through library or loan }\end{array}$ & 76 & 39 & 50 & 25.6 & 50 & 25.6 & 19 & 9.7 & 2.94 & important \\
\hline $\begin{array}{l}\text { The EFL Centre provides links } \\
\text { to materials online }\end{array}$ & 102 & 52.3 & 52 & 26.7 & 34 & 17.4 & 7 & 3.6 & 3.28 & Essential \\
\hline $\begin{array}{l}\text { The EFL Centre provides } \\
\text { support for learners with } \\
\text { disabilities }\end{array}$ & 127 & 65.1 & 51 & 26.2 & 13 & 6.7 & 4 & 2.1 & 3.54 & Essential \\
\hline
\end{tabular}

\section{Copyrights}

Copyright for this article is retained by the author(s), with first publication rights granted to the journal.

This is an open-access article distributed under the terms and conditions of the Creative Commons Attribution license (http://creativecommons.org/licenses/by/4.0/). 